\title{
Significant milestone for the Irish Veterinary Journal
}

\author{
Michael Doherty ${ }^{1 *}$, Simon J More ${ }^{1,2}$ and John F Mee ${ }^{3}$
}

\section{Editorial}

The Irish Veterinary Journal finds itself on an upward trajectory and we are delighted to announce that major progress has been made since the re-launch of the Irish Veterinary Journal as an open access journal within BioMed Central in March 2011.

The new Impact Factor for the journal, its first based solely on open access content, is 1.71, up from last year's 0.44 (Figure 1). This new Impact Factor sees the Irish Veterinary Journal, founded in 1946 and published in partnership with Veterinary Ireland, move up from the third quartile to the first quartile in the Veterinary Sciences category of this year's Journal Citation Report [1].

Scientific articles are now highly visible and accessible to all and over 75 peer-reviewed papers have been published online since the journal's re-launch. Web traffic to the website is substantial, and article accesses have increased almost six-fold between 2011 and 2014. Furthermore, access statistics for the 'most viewed' articles in the Irish Veterinary Journal are similar to those achieved by other journals in BioMed Central's veterinary portfolio, including BMC Veterinary Research. Articles are now routinely included in PubMed, PubMed Central and other international databases.

We have also had very positive feedback from authors who have submitted manuscripts for review following the re-launch. There has been a steady decrease between 2011 and 2014 in time from first to final editorial decision, reflecting high quality support from manuscript handling editors. Among authors, 93.6\% would publish again with the Irish Veterinary Journal, and 96.2\% would recommend the journal to a colleague. Average author satisfaction has been very high (4.4 on a scale of 1 (very poor) to 5 (very good)).

Since August 2012, the Irish Veterinary Journal has offered a 50\% discounted article processing charge for

\footnotetext{
* Correspondence: michael.doherty@ucd.ie

'UCD School of Veterinary Medicine, University College Dublin, Belfield,
}

Dublin 4, Ireland

\section{Biomed Central}

(c) 2014 Doherty et al.; licensee BioMed Central Ltd. This is an Open Access article distributed under the terms of the Creative Commons Attribution License (http://creativecommons.org/licenses/by/4.0), which permits unrestricted use, distribution, and reproduction in any medium, provided the original work is properly credited. The Creative Commons Public Domain Dedication waiver (http://creativecommons.org/publicdomain/zero/1.0/) applies to the data made available in this article, unless otherwise stated.

case reports, case studies and short reports, and these article types are now heavily represented among the submissions that we receive. These types of publications from veterinary practitioners are welcomed and are registrable for Continuing Professional Development (CPD) points with the Veterinary Council of Ireland. Biomed Central operates an Open Access Waiver Fund for authors based in countries classified by the World Bank in low-income or lower-middle-income economies, and these have been used extensively in the journal.

The relationship between the Irish Veterinary Journal and Animal Health Ireland has been a fruitful one, with a number of key influential papers published such as that on the cost-benefit of the national BVD eradication programme [2] and a series of papers on calf health [3-5]. Many articles have been highly accessed online including a demographic survey of unwanted horses in Ireland [6] as well as important reviews of IBR infection [7] and the use of bulk milk in the diagnosis of parasite infections [8]. We would like to thank all the authors who have contributed to the Irish Veterinary Journal and all of those colleagues who have provided invaluable editorial support and we look forward to increased numbers of manuscript submissions in the future.

Before joining the BioMed Central family in 2011, the Irish Veterinary Journal sat on the edge of the publishing abyss. The journal wasn't PubMed-cited and had an Impact Factor of 0.14. Its rise to 1.71 puts the journal in a new league and is a tribute to colleagues in BioMed Central, the Irish Veterinary Journal editorial team, and the open access process. This very significant milestone reflects the world-class aspirations of the Irish veterinary profession and of Irish veterinary science.

\section{Author details \\ 'UCD School of Veterinary Medicine, University College Dublin, Belfield, Dublin 4, Ireland. 'UCD Centre of Veterinary Epidemiology and Risk Analysis, UCD School of Veterinary Medicine, University College Dublin, Belfield, Dublin 4, Ireland. ${ }^{3}$ Animal and Grassland Research and Innovation Centre, Teagasc Moorepark, Fermoy, Co., Cork, Ireland.}

Received: 18 September 2014 Accepted: 9 October 2014 Published: 18 October 2014 


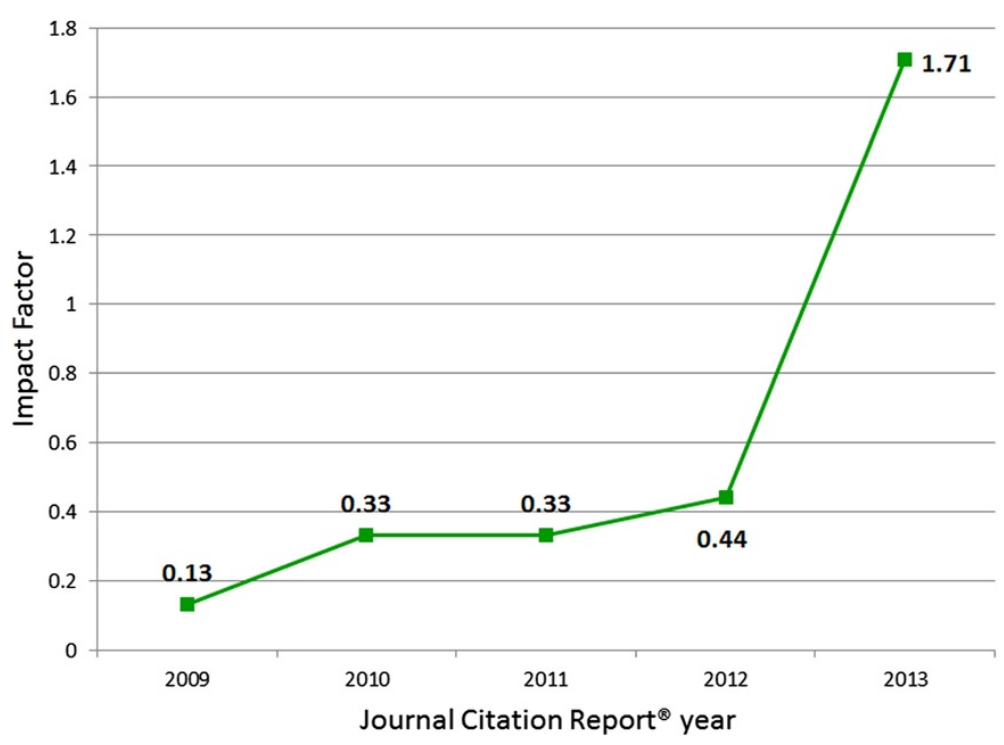

Figure 1 The Irish Veterinary Journal received its first Impact Factor based solely on open access content in the 2013 Journal Citation Report [1].

\section{References}

1. 2013 Journal Citation Reports ${ }^{\oplus}$. Thomson Reuters; 2014

2. Stott AW, Humphry RW, Gunn GJ, Higgins I, Hennessy T, O'Flaherty J, Graham DA: Predicted costs and benefits of eradicating BVDV from Ireland. Ir Vet J 2012, 65:12.

3. Lorenz I, Mee JF, Earley B, More SJ: Calf health from birth to weaning. I. General aspects of disease prevention. Ir Vet J 2011, 64:10

4. Lorenz I, Fagan J, More SJ: Calf health from birth to weaning. II. Management of diarrhoea in pre-weaned calves. Ir Vet J 2011, 64:9.

5. Lorenz I, Earley B, Gilmore J, Hogan I, Kennedy E, More SJ: Calf health from birth to weaning. III. Housing and management of calf pneumonia. Ir Vet J 2011, 64:14.

6. Leadon DP, Jeffery $R, O$ 'Toole $D$, Duggan V: A demographic survey of unwanted horses in Ireland in 2011 and totals for 2012 and a comparison with 2010. Ir Vet J 2013, 66:20.

7. Graham DA: Bovine herpes virus-1 (BoHV-1) in cattle-a review with emphasis on reproductive impacts and the emergence of infection in Ireland and the United Kingdom. Ir Vet J 2013, 66:15.

8. Sekiya M, Zintl A, Doherty ML: Bulk Milk ELISA and the diagnosis of parasite infections in dairy herds: a review. Ir Vet J 2013, 66:14.

doi:10.1186/2046-0481-67-23

Cite this article as: Doherty et al:: Significant milestone for the Irish Veterinary Journal. Irish Veterinary Journal 2014 67:23.

\section{Submit your next manuscript to BioMed Central and take full advantage of:}

- Convenient online submission

- Thorough peer review

- No space constraints or color figure charges

- Immediate publication on acceptance

- Inclusion in PubMed, CAS, Scopus and Google Scholar

- Research which is freely available for redistribution 